\title{
Chester porphyria: a clinical study of a new form of acute porphyria
}

\author{
MOHAMED R QADIRI, SUSAN E CHURCH, KENNETH E L McCOLL, \\ MICHAEL R MOORE, GILES R YOUNGS
}

\begin{abstract}
Acute porphyria afflicts a large kindred in Chester that stems from a marriage in 1896 that has produced 200 descendants; this is the largest porphyric kindred to be identified in the United Kingdom. Six members aged 51 or under died from the condition over the past eight years. The diagnosis of porphyria was overlooked in some as the symptoms may mimic those of other acute illnesses, so that incomplete or incorrect death certificates have been issued. Psychosis, hypertension, and renal complications are particularly common. The porphyric members of the kindred show a previously undescribed hereditary disorder in which the characteristic enzymatic defects of acute intermittent porphyria and variegate porphyria coexist in the same subject.

Acute porphyria is poorly understood by hospital and general practitioners, and this has caused anxiety in the kindred. A register of the kindred has been established, and families at risk should be offered biochemical screening, education, and genetic counselling.
\end{abstract}

\section{Introduction}

Three types of acute hepatic porphyria are recognised. Each is due to a partial deficiency of an enzyme in the pathway of biosynthesis of

Department of Medicine, Chester Royal Infirmary, Chester CH1 2AZ MOHAMED R QADIRI, MB, MRCP, medical registrar

SUSAN E CHURCH, MB, MRCP, medical registrar

GILES R YOUNGS, MD, FRCP, consultant physician

University Department of Medicine, Gardiner Institute, Western Infirmary, Glasgow

KENNETH E L MCCOLL, MD, MRCP, senior lecturer in medicine and consultant physician

MICHAEL R MOORE, BSC, PHD, senior lecturer in medicine

Correspondence to: Dr Youngs. haem inherited in an autosomal dominant fashion. All three disorders present with acute neuropsychiatric symptoms, of which abdominal pain is the most common and peripheral neuropathy the most life threatening. Acute intermittent porphyria was first accurately delineated by Waldenstrom in Sweden in $1937^{1}$ and appears to be due to a partial deficiency of porphobilinogen deaminase. ${ }^{2}$ It is the most common acute porphyria in Europe, where the highest prevalence recorded, estimated to be $1 / 1000$, is in Swedish Lapland. ${ }^{3}$ Variegate porphyria was first described in $1937^{4}$ and subsequently named by Dean and Barnes in 1955 in South Africa, ${ }^{5}$ where the prevalence is estimated to be $3 / 1000 .{ }^{6}$ Protoporphyrinogen oxidase is present in reduced amounts. ${ }^{7}$ This porphyria presents both with acute neuropsychiatric crises and with chronic skin eruptions. Hereditary coproporphyria is the least common of the acute porphyrias and is thought to be due to a relative deficiency of coproporphyrinogen oxidase..$^{810}$ The clinical features are similar to those of variegate porphyria except that the skin lesions are usually seen only in acute attacks.

Acute attacks of porphyria can be fatal, but death is generally believed to be less common now because precipitating factors, especially drugs, are recognised and can be avoided. ${ }^{611-14}$ This paper investigates a large kindred in Chester with acute porphyria characterised by appreciable morbidity and mortality. The study was stimulated by the complaint of a woman, whose husband and son had died of porphyria at the ages of 38 and 17, that hospital and general practitioners in Chester seemed unaware of the size of the problem and unable to provide informed counselling. We report the prevalence, clinical and biochemical features, and mortality of the condition and make recommendations concerning its management.

\section{Patients and methods}

The family tree was constructed from information obtained by word of mouth, home visits, hospital and general practitioners' notes, and study of certificates of births, baptisms, marriages, and deaths. Our study is largely retrospective, and some of our conclusions are based on circumstantial evidence, the medical records of those who died more than 10 years ago 
having been destroyed. Only four members of the kindred have been our patients, although we have seen and questioned many others for the purposes of this study. Biochemical methods are described elsewhere. ${ }^{\text {is }}$

\section{Results}

\section{THE KINDRED}

The kindred has been traced to a marriage in 1896 (fig 1). It is characterised by its fecundity ( 200 offspring to date) and the fact that most of its members are of low socioeconomic class; it also has a low rate of migration from Chester. The male spouse in the original marriage was illegitimate and is said to have taken his mother's name. We have failed to elicit any further details of this generation. We saw and tested the last survivor of the 10 children of the marriage (the second (II) generation, see table I) shortly before she died in 1982 aged 80 (subject II 4). Nine of the 10 siblings married and produced 40 cousins belonging to the third (III) generation. The 109 members of the fourth (IV) generation are now adolescents or young adults, eight of whom are already married and have produced 41 children to date. Tables I-III give biographical details of the members of the family believed to have porphyria. The pattern of inheritance is in keeping with Mendelian autosomal dominance.

Six of the 10 siblings are obligatory porphyrics because their descendants have proved porphyria (table I, fig 2). A seventh sibling (II 5) may have carried the gene as three of his sons (III 12,13,14) died in their teens, two from paralysis. Nineteen of the 40 cousins have porphyria (16 tested, three obligatory), or 22 if the three teenage brothers are included. Fifty nine of the

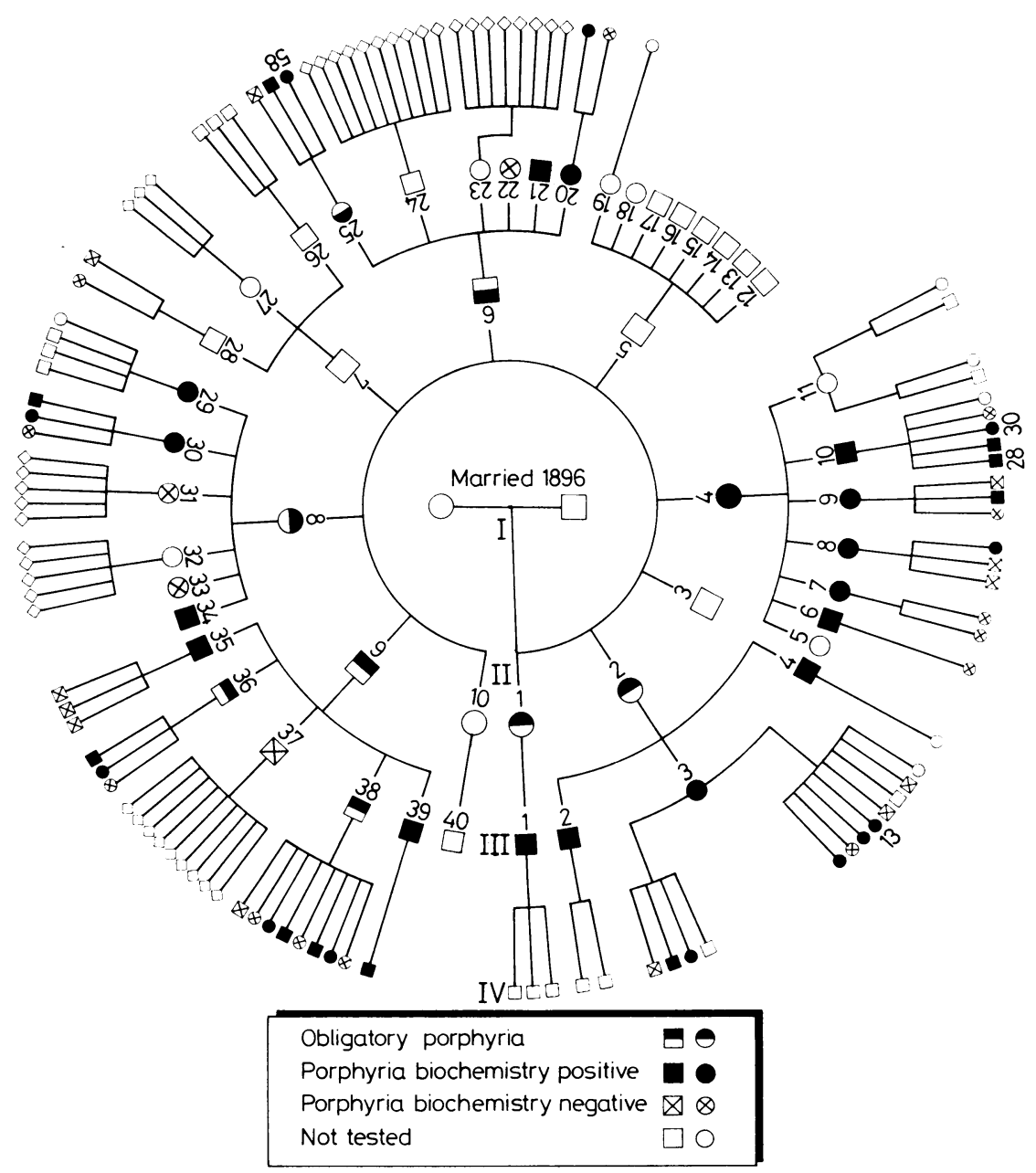

FIG 1-Family tree of kindred with Chester porphyria.

TABLE I-Details of second generation (10 siblings)

\begin{tabular}{|c|c|c|c|c|c|}
\hline $\begin{array}{l}\text { Family } \\
\text { notation }\end{array}$ & Sex & $\begin{array}{l}\text { Age at } \\
\text { death } \\
\text { (years) }\end{array}$ & $\begin{array}{l}\text { Details on death certificate } \\
\text { or cause of death }\end{array}$ & $\begin{array}{l}\text { Other previous } \\
\text { morbidity }\end{array}$ & Notes \\
\hline \multicolumn{6}{|c|}{ Subjects with porphyria } \\
\hline II 1 & $\mathrm{~F}$ & 58 & Hypertension, cerebrovascular accident & & Obligatory carrier \\
\hline II 2 & $\mathrm{~F}$ & 36 & Pneumonia, cerebrovascular accident & Abdominal pain, psychiatric illness & Obligatory carrier \\
\hline II 4 & $\mathrm{~F}$ & 81 & Senile dementia & & Obligatory carrier, porphyric biochemistry \\
\hline II 6 & $M$ & 40 & Pneumonia and paralysis & ? & Obligatory carrier \\
\hline II 8 & $\mathrm{~F}$ & 59 & No details & Abdominal pain, psychiatric illness & Obligatory carrier, porphyric biochemistry \\
\hline II 9 & $M$ & $84 ?$ & Pulmonary embolus, uraemia & Hypertension, abdominal pain & Obligatory carrier \\
\hline \multicolumn{6}{|c|}{ Subjects with possible porphyria } \\
\hline \multicolumn{6}{|c|}{ Porphyric state unknown } \\
\hline & $M$ & 40 & No details & & \\
\hline II 7 & $M$ & 40 & Died in psychiatric hospital & & \\
\hline II 10 & $\mathrm{~F}$ & ? & No details & & \\
\hline
\end{tabular}


109 members of the fourth generation are at risk of inheriting porphyria. Forty two of these ( 23 female) have been tested, of whom 21 ( 12 female) are positive. Only four have had symptoms, two of whom have died.

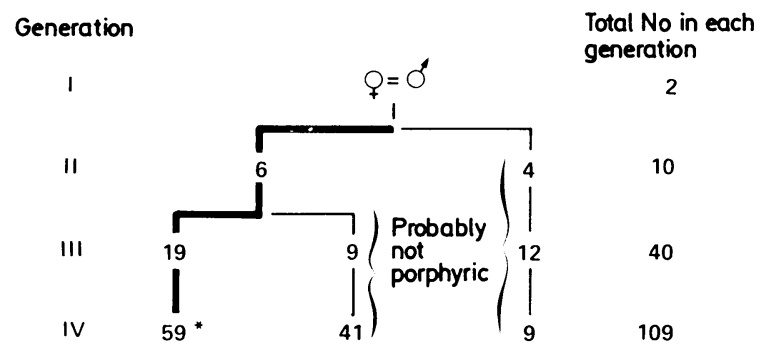

FIG 2-Abbreviated family tree of kindred with Chester porphyria showing (thick lines) numbers in each generation with porphyria.

${ }^{\star}$ Of 59 great grandchildren at risk, 42 have been tested biochemically, of whom 21 are positive for porphyria.

\section{MORTALITY}

Seventeen of the 40 cousins in the third generation, all of whom were born after 1923, have already died, 14 below the age of 52 (table II). Five died of the complications of hypertension and two of paralysis. Two members of the fourth generation have died of bulbar palsy (table III), a girl of 25 (IV 13) and a boy of 17 (IV 28). In the kindred as a whole six members have died aged 51 or less over the past eight years. Some have died suddenly after brief illnesses, which in retrospect we believe to have been porphyric. The fact that illnesses have been misdiagnosed and incorrect death certificates issued has become apparent only as a result of this survey.

\section{AGE AND SEX}

We have no information on age of onset of symptoms in the second generation. The 17 members of the third generation who experienced abdominal pain were troubled between their late teens and early 30 s. The four subjects in the fourth generation developed their pain at the ages of 16 16,19 , and 21 . We have no evidence of patients having acute abdominal symptoms after the age of 35 ; the morbidity and mortality of the condition

TABLE II-Details of third generation (40 grandchildren (cousins))

\begin{tabular}{|c|c|c|c|c|}
\hline $\begin{array}{c}\text { Family } \\
\text { notation }\end{array}$ & Sex & $\begin{array}{c}\text { Age at } \\
\text { death } \\
\text { (years) }\end{array}$ & Details on death certificate or cause of death & Morbidity \\
\hline \multicolumn{5}{|c|}{ Subjects with porphyria still alive (all biochemically positive) $(n=10)$} \\
\hline III 1 & $M$ & & & Hypertension \\
\hline III 2 & $M$ & & & Porphyric crisis, hypertension, psychiatric illness \\
\hline III 4 & M & & & $\begin{array}{l}\text { Porphyric crisis, psychiatric illness, hypertension, } \\
\text { renal failure }\end{array}$ \\
\hline III 6 & M & & & Porphyric crisis \\
\hline III 8 & $\mathrm{~F}$ & & & Latent porphyria \\
\hline III 9 & $\mathrm{~F}$ & & & Latent porphyria \\
\hline III 20 & $\mathrm{~F}$ & & & Hypertension, renal failure \\
\hline III 29 & $\mathrm{~F}$ & & & Porphyric crisis, psychiatric illness \\
\hline III 34 & $M$ & & & $\begin{array}{l}\text { Porphyric crisis, hypertension, renal failure, } \\
\text { psychiatric illness }\end{array}$ \\
\hline III 39 & M & & & Porphyric crisis, psychiatric illness \\
\hline \multicolumn{5}{|c|}{ Subjects with porphyria who have died $(n=9)^{\star}$} \\
\hline III 3 & $\mathrm{~F}$ & 48 & Hypertension, renal failure & Porphyric crisis \\
\hline III 7 & $\mathrm{~F}$ & 46 & $\begin{array}{c}\text { Hypertension, renal failure, } \\
\text { cerebrovascular accident }\end{array}$ & Porphyric crisis, malignant hypertension \\
\hline III 10 & M & 38 & $\begin{array}{l}\text { Malignant hypertension, } \\
\text { cerebrovascular accident }\end{array}$ & Porphyric crisis \\
\hline III 21 & $M$ & 48 & Hypertension, renal failure & Porphyric crisis \\
\hline III 25 & $\mathrm{~F}$ & 64 & Hypertension, cerebrovascular accident & \\
\hline III 30 & $\mathrm{~F}$ & 22 & Porphyric crisis, paralysis & \\
\hline III 35 & $M$ & 60 & ? Cause & Porphyric crisis, psychiatric illness \\
\hline III 36 & $M$ & 30 & Porphyric crisis, paralysis & \\
\hline III 38 & $M$ & 51 & $\begin{array}{l}\text { Heart failure, bronchitis (clinical } \\
\text { meningitis. Negative necropsy findings) }\end{array}$ & Psychiatric illness \\
\hline \multicolumn{5}{|c|}{ Subjects (siblings) with possible porphyria (all dead) $(n=3)$} \\
\hline III 12 & $M$ & 16 & & \\
\hline III 13 & M & 20 & $\begin{array}{l}\text { All had abdominal } \\
\text { pain; } 2 \text { died from paralysis }\end{array}$ & \\
\hline 1114 & $\mathbf{M}$ & 18 & & \\
\hline \multicolumn{5}{|c|}{ Porphyric state unknown $(n=13)$} \\
\hline III 5 & $\mathrm{~F}$ & 3 & & \\
\hline III 16 & $M$ & 60 & ? Cause & \\
\hline III 26 & $M$ & 35 & Postoperative death (no details) & \\
\hline III 32 & $\mathrm{~F}$ & $30 \mathrm{~s}$ & Death in childbirth & \\
\hline III 40 & $M$ & & & \\
\hline \multicolumn{5}{|c|}{ Eight subjects are still alive with no known porphyric symptoms } \\
\hline & & & Subjects without porphyria $(n=5)$ & \\
\hline
\end{tabular}

*Six biochemically positive, three obligatory carriers.

If we assume that half the 59 members of the fourth generation at risk in fact carry the gene then about 56 people from the kindred as a whole (one from the first generation, six from the second, 19 from the third, and 30 from the fourth) carry or have been carriers of the porphyric gene. An estimated 37 of these are still alive (nine in the third generation and 28 in the fourth) giving a prevalence of porphyria in the city of Chester of roughly $1 / 1600$ $(37 / 60000)$. This does not take into account the 41 great great grandchildren born so far, who are currently not old enough for their condition to be accurately assessed. We do not know of any people in Chester with acute porphyria who are not members of the kindred. thereafter is due to cerebral crises (III 10 and 38) or to hypertension and renal failure. Of the 46 subjects with porphyria in the second, third, and fourth generations, 22 are male. Six of the 11 who have died under the age of 52 were male.

\section{PRECIPITATING FACTORS}

Three subjects (III 10, 21, 29) developed porphyric crises after surgical procedures, but the nature of the anaesthetic is unknown. Barbiturates were 
so widely used in psychiatric practice that they may have contributed to the deaths of two subjects (II 2 and 7), who died in the Chester psychiatric hospital aged 36 and 40 respectively. The first member of the kindred to be diagnosed as having acute porphyria (III 7) presented in 1954 with malignant hypertension and then developed psychosis and paralysis, perhaps after treatment with barbiturates. Her porphyria subsequently complicated her pregnancies. ${ }^{16}$ One man (III 39) developed an acute abdomen in 1962 and was given phenobarbitone. He developed a confusional state, which became worse when the drug was again administered as an aid to electroencephalographic diagnosis. His porphyric state was established only during the present survey.

Two young women (IV 13, 30) have had 31 admissions with acute porphyric crises. The attacks usually start about five days premenstrually, but drugs, including oral contraceptives, have never been implicated. porphobilinogen deaminase and protoporphyrinogen oxidase, each being depressed to an extent similar to that seen in the two separate forms of acute porphyria, acute intermittent and variegate porphyria. Of the 14 subjects with porphyria in whom both haem biosynthetic enzymes were measured including seven in the fourth generation, none could be convincingly shown to have the enzyme pattern of acute intermittent porphyria or variegate porphyria on its own. o-Aminolaevulinic acid synthase is increased to an extent similar to that seen in the two separate porphyrias. The excretion pattern in urine and faeces in the Chester kindred is also unusual, varying between affected individuals from that characteristic of acute intermitten porphyria to that characteristic of variegate porphyria, with several subjects showing an intermediate excretion pattern. There was no significan association between the excretion pattern and the activity of either porphobilinogen deaminase or protoporphyrinogen oxidase.

TABLE III-Details of fourth generation (109 great grandchildren)

\begin{tabular}{|c|c|c|c|c|}
\hline $\begin{array}{c}\text { Family } \\
\text { notation }\end{array}$ & Sex & $\begin{array}{c}\text { Age at } \\
\text { death } \\
\text { (years) }\end{array}$ & Details on death certificate & Notes \\
\hline \multicolumn{5}{|c|}{59 subjects have porphyric parent; of 42 tested, 21 are positive, of whom 4 are symptomatic } \\
\hline $\begin{array}{l}\text { IV } 13 \\
\text { IV } 28\end{array}$ & $\begin{array}{l}\mathrm{F} \\
\mathrm{M}\end{array}$ & $\begin{array}{l}25 \\
17\end{array}$ & $\begin{array}{l}\text { Acute porphyria } \\
\text { Acute porphyria }\end{array}$ & \\
\hline IV 30 & $\mathrm{~F}$ & & & $\begin{array}{l}\text { Sister of IV 28. Has had } 15 \text { admissions with acute } \\
\text { porphyric crisis }\end{array}$ \\
\hline IV 58 & $\mathbf{F}$ & & & Typical but mild crisis in 20 s; asymptomatic since \\
\hline \multicolumn{5}{|c|}{41 subjects have parents not thought to be porphyric } \\
\hline \multicolumn{5}{|c|}{9 subjects have grandparents and therefore parents not thought to be porphyric } \\
\hline
\end{tabular}

\section{CLINICAL FEATURES}

The porphyric symptoms and signs in our kindred fall within the range of those described in the acute porphyrias. ${ }^{17}$ Skin lesions have not been seen. We have seen classical porphyric crises with abdominal pain often accompanied by neuropathy in two patients (IV 13, 30) on a total of 31 occasions. Two older subjects died after cerebral crises of brief duration: one (III 10) died aged 38 within 24 hours after admission to hospital, the cause of death being given as cerebral haemorrhage, malignant hypertension, and porphyria; the other (III 38) died within 48 hours after developing headache and meningism but was normotensive. No cerebral disease was found at necropsy, and the fact that he was an obligatory carrier was established only during this study.

Hypertension, hyponatraemia, and uraemia were a common feature in the two subjects admitted on 31 occasions (IV 13, 30); values returned to normal between attacks. In the third generation, of 40 cousins, sustained hypertension (10 subjects) and renal impairment (seven) were surprisingly common among the subjects with porphyria but were not seen in the normal subjects.

Ten of the 25 members of the second and third generations known to have porphyria have been admitted to psychiatric hospitals, and we do not know of any members without porphyria similarly afflicted. In acute porphyric crises emotional retardation and distress are invariable but frank psychosis is rarely seen. Hysteria was suspected in one subject (IV 28), who was given an injection of sterile water the evening before he died aged 17. Three subjects (III 7, 29, 39) were transferred to psychiatric care because of acute psychoses complicating treatment with barbiturates for other conditions. Seven other members had chronic psychiatric conditions.

\section{LATENT PORPHYRIA}

Three of the 19 cousins with porphyria appear never to have had symptoms, although one has hypertension. The fact that many carriers are asymptomatic is shown by the fourth generation. Only four of the 59 children with a parent with porphyria have had symptoms, of whom two have died (IV 13, 28). We have no knowledge of attacks in others, although some are still adolescents and many we have not met. Some subjects have had only brief episodes: one (III 29) had no porphyric symptoms until she had an anaesthetic for a gynaecological procedure in her mid-20s. She developed a severe psychiatric disturbance postoperatively and was gravely ill for several days. She recovered and has been asymptomatic ever since.

\section{BIOCHEMICAL FEATURES}

The features of the abnormal biosynthesis of haem in the Chester kindred are described in detail elsewhere. ${ }^{15}$ There is an unusual deficiency of both

\section{Discussion}

This Chester kindred appears to be unique in Great Britain both for its size and for the unusual biochemical features, which are not typical of any of the three recognised acute hepatic porphyrias. The concentration of cases is enhanced by 19 (possibly 22) of the 40 cousins having inherited the condition-statistically only a quarter of the generation would be expected to have inherited it - and by the low migration rate, as all 10 of the original siblings remained in Chester and only three of the 40 members of the next generation left the city.

The acute porphyria seen in this kindred is the result of a previously undescribed hereditary disorder of haem biosynthesis in which the characteristic enzymatic defects of acute intermittent porphyria (porphobilinogen deaminase) and variegate porphyria (protoporphyrinogen oxidase) coexist in each affected subject. ${ }^{15}$ The genetic basis of this dual enzyme defect is not clear. The pattern could be the result of coincidental inheritance of the genetic defects for both acute intermittent and variegate porphyria. Coincidental inheritance of both variegate and cutaneous hepatic porphyria has been described. ${ }^{18}$ Patients have also been reported as having inherited two dominant genes for hereditary coproporphyria, resulting in a particularly severe form of the disorder..$^{19}$ If the genes for acute intermittent and variegate porphyria coexist in this kindred, however, it is surprising that no subject has been found to have the enzyme pattern of either form of acute porphyria on its own unless the two genes are closely linked and therefore coinherited. The locus for porphobilinogen deaminase is sited on chromosome eleven but that for protoporphyrinogen oxidase has not yet been mapped.

Our observation and that of Meissner et al that porphobilinogen deaminase is slightly reduced in variegate porphyria ${ }^{15}{ }^{20}$ makes it possible that the Chester kindred represents an extreme example of variegate porphyria in which the porphobilinogen deaminase activity in some of the subjects is sufficiently reduced to become rate controlling, thus altering the porphyrin excretion pattern from that of variegate porphyria to that of acute intermittent porphyria.

Until we have defined more accurately the genetic basis of the porphyria described in this paper it is premature to name it and perhaps best to use the eponym "Chester porphyria." Its essential characteristic is the double enzyme deficiency, but the term "dual porphyria" has been used to describe coexisting variegate and 
cutaneous hepatic porphyria. ${ }^{18}$ The kindred have their own epithet -namely, "Dobson's complaint," Dobson being the family name stemming from the marriage of 1896. Similarly, Dean in his classical family study of variegate porphyria in South Africa found the condition already named by the kindred as "van Rooyen skin."”

The clinical course of the Chester porphyria illustrates many of the previously reported features of this group of conditions, but the fact that six members have died aged 51 or less in the past eight years leaves no room for complacency. One characteristic that hindered our study was the protean manifestations of the disease, which makes it difficult in retrospect to ascertain the true cause of death in our subjects, especially when medical records are not available. The variability of the clinical manifestation was recognised by Waldenstrom, ' who added acute porphyria to hysteria and syphilis as deserving the epithet "la petite simulatrice." ${ }^{21} \mathrm{He}$ emphasised that a porphyric attack-the widespread pains, curious pareses, and frequent emotional disturbance often with vague physical signs and normal results of investigations - could easily be mistaken for hysteria. It is thus not surprising that incorrect diagnoses are made, and our study is no exception. In the early part of the study psychotic reactions to barbiturates went unrecognised, and more recently the complications of hypertension and renal failure have been neglected.

The stimulus for our study was the observation by the mother of a boy (IV 28) who had died at the age of 17, whose husband (III 10) had died at the age of 38 and whose daughter (IV 30) had had 15 admissions with porphyric crises, that both hospital and general practitioners seemed to know little about acute porphyria and that the medical profession in Chester seemed unaware that several members of the kindred had died of the condition at a young age in the recent past.

We have established a register of the subjects with porphyria, and hospital, general, and community health medical practitioners have been sent an explanatory leaflet. Members of the kindred are offered screening tests and the services of the genetic counselling clinic. Their hospital notes are marked, and they are warned to report their porphyria if any surgical procedure is contemplated. Some wear alert bracelets. A current list of permitted drugs is available from the Porphyrias Service in Glasgow. A protocol outlining the hospital management of acute crises and emphasising the dangers of hyponatraemia and bulbar palsy has been prepared. We are screening as many adult members as possible for hypertension and renal failure.

The story of our kindred illustrates the hazards of a rare condition that presents in protean ways. Our subjects have presented with acute symptoms to general physicians and surgeons, psychiatrists, and anaesthetists; porphyria has complicated the attentions of gynaecologists, obstetricians, and ear, nose and throat surgeons; specialist opinions have been sought from neurologists and nephrologists. Truly the Chester porphyria deserves the epithet "la petite simulatrice."

We are grateful to the many hospital and general practitioners in Chester for allowing us to study their patients, and to members of the kindred who helped construct the family tree. Valuable advice was given by Professor $\mathrm{Sir}$ Abraham Goldberg and Dr Geoffrey Dean. Miss G Whitefoot prepared the references and Mrs L Tehrani and Miss A Harding the illustrations. Special thanks are due to Mrs M A Willetts, who typed the manuscript and supervises the patient follow up and register. The biochemical assays were performed by Mr G G Thompson.

GRY is grateful to Mr P N Meissner and Mrs D Meissner for the hospitality of the Porphyria Research Laboratory, Groote Schuur Hospital, Cape Town, South Africa. He was in receipt of a Royal College of Physicians Medicine-Gilliland travelling fellowship and is supported by the Mason Medical Research Foundation.

\section{References}

1 Waldenstrom J. Studien über Porphyrie. Acta Med Scand 1937: suppl 82.

2 Brodie MJ, Moore MR, Goldberg A. Enzyme abnormalities in the porphyrias. Lancet 1977;ii: 699-701.

3 Goldberg A, Rimington C. Diseases of porphyrin metabolism. Springfield, Illinois: Charles C Thomas, 1962

4 Van den Bergh AA, Grotepas W. Ein Bemerkenswerter von Porphyrie. Wien Klin Wocheschr 1937;50:830-1

5 Dean G, Barnes HD. The inheritance of porphyria. Br Med f 1955;ii:89-94.

6 Dean G. The porphyrias: a story of inheritance and environment. 2nd ed. London: Pitman, 1971

7 Brenner DA, Bloomer JR. The enzymatic defect in variegate porphyria. $N$ Engl f Med 1980;302:765-9.

8 Berger H, Goldberg A. Hereditary coproporphyria. Br Med f 1955;ii:85-8.

9 Elder GH, Evans JO, Thomas N, et al. The primary enzyme defect in hereditary coproporphyria. Lancet 1976;ii:1217-9.

10 Brodie MS, Thompson GG, Moore MR, Beattie AD, Goldberg A. Hereditary coproporphyria. $Q$ 7 Med 1977;46:229-41.

11 Stein JA. Tschudy DP. Acute intermittent porphyria: a clinical and biochemical study of 46 patients. Medicine (Baltimore) 1970;49:1-16.

12 Mustajoki P, Koskelo P. Hereditary hepatic porphyrias in Finland. Acta Med Scand 1976;200: 171-8.

13 Eales L, Day RS, Blekkenhorst GH. The clinical and biochemical features of variegate porphyria: an analysis of 300 cases studied at Groote Schuur Hospital, Cape Town. Int $\mathcal{f}$ Biochem $1980 ; 12: 837-53$

14 Disler PB, Moore MR. The acute attack of porphyria. In: Disler PB, Moore MR, eds. Clinics in dermatology. Philadelphia: Lippincott, 1985:103-11.

15 McColl KEL, Thompson GG, Moore MR, et al. Chester porphyria-biochemical studies of a new form of acute porphyria. Lancet 1985; ii:796-9.

16 Porteous CR. A case of porphyria complicated by pregnancies. Journal of Obstetrics and Gynaecology of the British Commonwealth 1963;70:311-4.

17 Goldberg A. Acute intermittent porphyria: a study of 50 cases. Qf Med 1959;28:183-209.

17 Goldberg A. Acute intermittent porphyria: a study of 50 cases. Qf Med 1959;28:183-209. Day RS, Eales L, Meissner D.
N Engl f Med 1982;307:36-41.

19 Grandchamp B, Phung N, Nordmann Y. Homozygous case of hereditary coproporphyria. Lancel 1977; ii:1348-9.

20 Meissner PN, Sturrock ED, Maeder DL, Moore MR. Porphobilinogen deaminase uroporphy rinogen decarboxylase and protoporphyrinogen oxidase in variegate porphyria. Biochem Soc Trans 1985;13:204-5.

21 Waldenstrom J. Neurological symptoms caused by so called acute porphyria. Acta Psychiatrica e Neurologica Scandinavica 1939;14:375-9.

(Accepted 30 October 1985)

\section{MATERIA NON MEDICA}

\section{Doctor and saint}

We had to wait until the long procession had passed before we could cross the wide grass park where in days gone by the English had shown the Corfiots the game of cricket. It was Palm Sunday, some years ago, and the procession was the occasion for the patron saint of Corfu, St Spiridion, to be paraded through the town. The rest of the procession was a curious mixture of religion, militarism, and youth, for there were priests in their glorious robes and tall hats, soldiers with fixed bayonets, sea scouts, and girl guides. It was difficult not to feel irreverently amused by the sight of the saint's remains in his glass coffin.

At length the mile long procession passed. We crossed the wide green and walked to a country village on the hill among the olive trees. A woman with two goats approached. "Americano?" she asked and seemed to understand our reply, "British." She beckoned us to follow and left her goats outside the largest house in the village, motioning us to stay on the veranda as she disappeared into the house. She reappeared and ushered us into a room in which a very old and distinguished looking lady was playing patience, in her dressing gown, at a bare wooden table.
"I am so glad to speak English with someone ... it is so long since I have had the chance. I am Portuguese." But her English did not betray the fact. Pointing to a photograph of herself as a young woman in court dress, she said that she was the widow of a diplomat, at one time ambassador to Russia. He had been rich and had acquired property in Russia, only to lose it in the Bolshevik revolution and become impoverished.

We mentioned St Spiridion, fortunately without any hint of irreverence, and her eyes brightened as she told us of her faith in the saint. Many years ago her daughter had been dangerously ill and the doctors had given no hope for her recovery. She had gone to the cathedral in Corfu Town to pray for her daughter at the coffin of St Spiridion. So overcome was she with stress and anxiety that she broke down in tears and found she could not pray. A priest approached and, learning of her distress, said that he would pray for her, which he did.

She went on her way and returned to the sickbed to find her daughter's condition had suddenly improved and she was starting on the road to recovery.

A miracle effected by prayer, or a dramatic crisis in a lobar pneumonia such as we used to witness? Perhaps both. - $\mathrm{s}$ J HADFIELD, Oban, Argyll. 